\title{
ASPECTOS GEOMORFOLÓGICOS E ANÁLISE GEOECOLÓGICA EM UNIDADES DE CONSERVAÇÃO: ESTUDO DE CASO NO PARQUE NATURAL MUNICIPAL MONTANHAS DE TERESÓPOLIS
}

\section{Geomorphological aspects and geoecological analysis in conservation units: case study in the municipal natural park of Teresópolis}

\author{
Gabriela Garcia Santana Lopez \\ Doutoranda em Geografia - PUC-RJ \\ gabigarcialopez@gmail.com \\ Otavio Miguez Rocha Leão \\ Professor Adjunto UERJ-FFP-DGEO \\ orochaleao@hotmail.com
}

\begin{abstract}
Artigo enviado para publicação em 13/08/2018 e aceito em 24/09/2018
\end{abstract}
DOI: $10.12957 /$ tamoios.2018.36662

\section{RESUMO}

Esse artigo enfoca as relações entre a sociedade e a natureza para a delimitação de uma área de conservação. Pautada na perspectiva dos Geossistemas tem como objetivo realizar uma análise geoecológica, com ênfase na geomorfologia, da área do Parque Natural Municipal Montanhas de Teresópolis e de suas relações com o processo de ocupação dos entornos. A delimitação da área do parque, localizado na região serrana do estado do Rio de Janeiro, desconsiderou o aspecto geossistêmico do ambiente, que integra sociedade e natureza em um sistema que possui elevada suscetibilidade a distúrbios em sua estabilidade. Durante um evento catastrófico em que ocorreram inúmeros deslizamentos em janeiro de 2011, no qual mais de 390 pessoas morreram apenas em Teresópolis, o sistema ambiental da área do parque foi atingido, tanto nas áreas protegidas quanto nas áreas de ocupação urbana, negligenciadas por politicas habitacionais ao longo da historia do município, e também, durante a delimitação da área do parque. O PNMMT possui a maior parte de sua área inserida no domínio montanhoso e, diante disso, torna-se mais susceptível a processos erosivos à medida que há uma atuação em conjunto com outros fatores hidrológicos e geomorfológicos. Esse artigo pretende apontar as contradições na delimitação da unidade de conservação e sua ineficiência em proteger o geosssistema montanhoso e as populações que habitam em suas proximidades.

Palavras-chave: Unidades de Conservação; Geomorfologia; Geossistemas.

\begin{abstract}
This article focuses on the relationships between society and nature, for the delimitation of a conservation area. Based on the Geosystems' perspectives, the objective is to do a geoecological analysis, with emphasis on geomorphology, of the municipal natural park of Teresópolis and its relations with the process of the occupation of its surrounds. Located in the mountains region of the Rio de Janeiro state, during the delimitation of this park area, man and nature were separated, disregarding the integration of both into a single system and, consequently, susceptible to disturbances in their stability in the face of mistaken human interference. During a catastrophic event in which there were countless landslides in January 2011, in which more than 390 people died only in Teresópolis, the environmental system of the park area was reached, both in protected areas and in urban occupation areas. The greater part of the PNMMT area is in a mountaneous domain and, in this way, becomes more susceptible to erosive processes, as there's a joint action with others hydrological and geomorfologycal factors. This article aims to point out the contraditions in the delimitation of the conservation unit and its inefficiency in protecting the mountainous geosystem and the populations that live in its vicinity.
\end{abstract}

Keywords: Conservation Units; Geomorphological; Geosystems. 


\section{INTRODUÇÃO}

As concepções do homem acerca do meio ambiente, muitas vezes variam de acordo com as formações sociais no qual este está inserido. Logo, estas distintas visões, embora muitas vezes generalistas, acarretam as mais diversas ações do homem na natureza, seja buscando a sua preservação, seja degradando-a. Implantadas no Brasil com base em uma perspectiva preservacionista, o poder público vem ao logo dos anos, instituindo Unidades de Conservação com o objetivo de conservar a biodiversidade. Deste modo, muitas vezes tem-se uma visão da natureza como externa ao homem durante o processo de criação destas unidades. Ignora-se muitas vezes, a importância do homem como agente direto ou indireto na preservação do meio ambiente, uma vez que ambos estão inseridos no mesmo sistema. Em outros momentos, é permissivo, com a presença maciça deste mesmo diante de características naturais que evidenciam que esta pode ser prejudicial tanto para o homem, quanto para a área a qual se busca preservar.

Neste artigo, será questionada a delimitação da área do Parque Natural Municipal Montanhas de Teresópolis. Embora o conceito de Natureza possa ser compreendido de diferentes formas, conforme a formação social na qual está inserido, partiremos de uma concepção de que esta não pode ser entendida como externa ao Homem e, por tanto, disponível para ser utilizada sem maiores preocupações a partir de sua dominação.

Mendonça (2004) faz uso do termo socioambiental, uma vez que é insuficiente falarmos de meio ambiente apenas no ponto de vista da natureza. Neste caso, à medida que os termos sociedade e natureza aparecem entrelaçados, enfatiza-se a importância do envolvimento da sociedade enquanto sujeito fundamental dos processos que envolvem a problemática ambiental atual. Tal dicotomia da relação sujeito-objeto também é rompida com Kant, segundo Moreira (2009), ao colocar os homens e os fenômenos dentro de uma mesma relação no mundo.

É justamente essa evolução do modo de se pensar a Natureza, que pode desencadear, por parte do homem, as mais diversas ações, seja entendendo-a como recurso ou buscando medidas para sua preservação. Entretanto, para que tais medidas sejam efetivas, é necessário o entendimento da Natureza como um sistema único. Dessa maneira torna-se necessário uma abordagem integrada de fenômenos físicos e sociais presentes na natureza, que se entrecruzam na formação de geossistemas impregnados das ações humanas, sendo que a delimitação de Unidades de Conservação está diretamente associada ao entendimento das relações entre a sociedade e a natureza. No presente artigo será realizado um estudo sobre os aspectos geomorfológicos das encostas presentes no Parque, com ênfase em sua dinâmica hidro erosiva e em suas relações com os fundos de vale adjacentes, que compõem áreas de expansão da ocupação humana em Teresópolis. Em um segundo momento será destacada a influência da geomorfologia nos geossistemas montanhosos e na Geoecologia da Paisagem. Também é apresentado um quadro descritivo do PNMMT com ênfase em seu histórico de uso e na sua caracterização geomorfológica. Por fim apresenta-se uma síntese das principais características morfométricas e geomorfológicas do geossistema montanhoso e as contradições entre a dinâmica ambiental, hidrológica e erosiva com a delimitação da Unidade de Conservação. 


\section{HIDROLOGIA DE ENCOSTAS E PROCESSOS GEOMORFOLÓGICOS RELACIONADOS A MOVIMENTOS DE MASSA}

Na composição da paisagem terrestre, a água é um elemento físico de suma importância. Segundo COELHO NETTO (2013), cabe ela a função de interligar fenômenos da atmosfera inferior a da litosfera, além de interferir na vida vegetalanimal e humana, à medida que interagem com os demais elementos de seu ambiente de drenagem. Entretanto, seu papel de destaque está na função de agente modelador do relevo terrestre, no qual tem relação direta com o domínio das encostas. Como encostas, temos como base a definição da autora, de que estas são os espaços físicos situados entre os fundos de vales e os topos ou cristas da superfície crustal, os quais definem as amplitudes de relevo e seus gradientes topográficos.

A morfologia das encostas pode assumir diferentes formas geométricas que resultam de ações erosivas e deposicionais ocorridas ao longo do tempo, e, que podem afetar a erodibilidade dos solos, tais como declividade, comprimento e forma da encosta. Estas características atuam em conjunto e, com outros fatores relacionados à erosividade da chuva que, segundo ROCHA-LEÃO (2005) está relacionada à quantidade de chuva precipitada, sua intensidade e duração do evento chuvoso, assim com também, à energia cinética das gotas. Porém, o autor enfatiza que o trabalho erosivo será produto de uma combinação de fatores, no qual a precipitação é considerada um dos mais importantes, à medida que condiciona a quantidade de água disponível para remoção de materiais do solo, influenciando também a umidade antecedente no ambiente. A intensidade da chuva tem papel importante no que diz respeito às taxas de infiltração, que por sua vez está relacionada com as propriedades do solo, as características da encosta, a cobertura vegetal e o tipo de chuva.

Os processos erosivos são constituídos pela remoção, transporte e deposição de sedimentos, que ocorre a partir do momento em que não há mais energia para continuidade do transporte. GUERRA (2013) ressalta que a erosão ocorre a partir do momento em que as forças que removem e transportam materiais excedem aquelas que tendem a resistir à remoção. Deste modo, várias propriedades do solo que afetam sua erosão, tais como a textura, a densidade aparente, a porosidade, o teor e estabilidade dos agregados e os $\mathrm{pH}$ dos solos naturais. Assim sendo, as encostas podem ser classificadas em segmentos côncavos, convexos ou retilíneos, com a passibilidade de haver uma combinação entre estas formas. Consequentemente, há uma influencia no direcionamento dos fluxos da água no solo, o que permite a distinção dos processos hidroerosivos que atuam em cada ponto da encosta conforme o tipo de fluxo: convergente, divergente ou paralelo.

A morfologia das encostas, uma vez que é um fator condicionante do direcionamento dos fluxos hidrológicos nas vertentes, exerce influencia nas rotas de drenagem superficial e subsuperficial. Estas por sua vez, são definidas por variáveiscontrole dos processos de infiltração, a partir do momento que a água da chuva atinge o solo de uma encosta. Quando a capacidade de infiltração do solo é superada pela intensidade da precipitação, há o escoamento superficial ou hortoniano. Logo, tem-se no fluxo subsuperficial raso, o resultado da associação de solos superficiais altamente permeáveis com vertentes íngremes. Já em áreas que apresentam cobertura vegetal, a água tende a percolar em subsuperfície, onde a percolação se dirige do topo para a base da encosta, não havendo assim o fluxo superficial. O fluxo de retorno ocorre quando a água percolada em profundidade aflora nos segmentos de baixa encosta. Esse, quando associado à precipitação direta na base da encosta e nos fundos de vale que ficam saturados, geram o fluxo subsuperficial de saturação. 
COELHO NETTO (2013) destaca ainda a importância que a influência da interação de diversos fatores bióticos, abióticos e antrópicos exercem na definição das rotas preferenciais dos fluxos superficiais e subsuperficiais. Em condições normais de mensuração, o movimento da água sobre a superfície é mais rápido e torna-se lento conforme a profundidade, exemplificando assim, a importância do fator solo. Este pode determinar o volume do escoamento da chuva, a sua distribuição temporal e as descargas máximas, em superfície e em subsuperfície. Assim, temos nos fluxos superficiais um importante modelador do relevo, na medida em que estes são capazes de erodir o topo dos solos e remover os nutrientes básicos para o crescimento dos vegetais. Logo, quando algum desses fatores sofre alterações na sua composição, pode haver modificações consideráveis na dinâmica espaço-temporal dos processos hidrológicos atuantes na encosta.

É importante ressaltar, que as unidades que compõe o relevo, à medida que apresentam um conjunto de canais de escoamento inter-relacionados, compõe a bacia de drenagem. CHRISTOFOLETTI (1980) define bacia de drenagem como sendo a área drenada por um determinado rio ou por um sistema fluvial. O limite destas bacias será determinado por um divisor de drenagem. COELHO NETTO (2013) atenta que a bacia de drenagem pode se desenvolver em diferentes tamanhos, no qual as de poucos metros irão se articular com os divisores de drenagem principais como parte de um sistema organizado hierarquicamente.

Acerca das alterações na composição ambiental de determinada porção da bacia de drenagem, COELHO NETTO (2013) ressalta que os efeitos hidrológicos e geomorfológicos de processos naturais ou antrópicos irão se refletir num determinado ponto de saída de uma bacia, podendo haver a propagação à jusante por meio de bacias de drenagem adjacentes. Deste modo, podemos considerar as bacias hidrográficas como sistemas abertos, uma vez que há o ganho e a perda de energia e matéria, relacionados à água e sedimentos oriundos de erosão fluvial e das encostas existentes nas bacias.

Uma vez que compreendemos que o ciclo hidrológico é crucial para o inicio do processo erosivo, podemos distinguir algumas categorias mais importantes na morfogênese do relevo terrestre. Durante um evento chuvoso, parte da água cai diretamente no solo e parte da água é interceptada pela copa das árvores. Desta água interceptada, uma parte evapora e a outra chega ao solo por gotejamento ou pelo fluxo de tronco. GUERRA (2013) aponta que o processo erosivo tem inicio a partir do splash, que é decorrente do gotejamento das folhas e causador de crostas na superfície que dificultam a infiltração. Logo, poças são formadas nas irregularidades existentes no topo do solo e, a partir do momento que estas são rompidas, seja por transbordamento ou pelo próprio volume da água, tem inicio o processo de escoamento superficial. Quando o escoamento superficial deixa de ser difuso e passa a ser linear, começa a ocorrer a formação de microrravinas, que posteriormente evoluem para microrravinas com cabeceiras e ravinas. À medida que o fluxo de água canalizada nas ravinas continuar aprofundando e alargando as feições erosivas, temos as voçorocas.

A partir da compreensão da hidrologia de encostas, entendemos que os movimentos de massa possuem também importante papel como agente modelador do relevo, à medida que são fenômenos naturais, que fazem parte da dinâmica externa terrestre. O Brasil, de acordo com FERNANDES \& AMARAL (2011), possui condições climáticas e grandes extensões de maciços montanhosos e, por isto, está sujeito a desastres associados aos movimentos de massa nas encostas. Além disso, é importante também considerar que apesar de ser um fenômeno natural, a ação do homem como um fator indutor destes movimentos. Diante de vários tipos de movimento de massa, são utilizados critérios para a diferenciação destes, tais como: tipo de material, 
velocidade e mecanismo do movimento, o modo de deformação, a geometria da massa movimentada e o conteúdo da água.

Dentre as diversas tipologias de movimentos de massa, abordaremos os deslizamentos de encostas, uma vez que na presente área de estudo, estes são os predominantes. Acerca de tais movimentos, CHRISTOFOLETTI (1980) os caracteriza como gravitacionais, pois promovem a movimentação de partículas ou parte do solo pela encosta abaixo. Ressalta ainda, que implicitamente, a única força levada em conta é a gravidade e que nenhum meio de transporte, como o vento ou a água em movimento, está envolvido diretamente, embora esta última desempenhe papel importante ao aumentar o peso da massa intemperizada.

As corridas (flows) são movimentos rápidos, normalmente associados à concentração excessiva de fluxos de água superficiais em determinado ponto da encosta e que, consequentemente, deflagram um processo de fluxo continuo de material terroso segundo FERNANDES \& AMARAL (2011). Os escorregamentos são movimentos rápidos, que podem ocorrer em minutos e prolongar-se por algumas horas. Segundo SUERTEGARAY (2008), estão relacionados a descidas de solos ou massas de rochas decompostas, geralmente por efeito da gravidade em estruturas inclinadas. Logo, tal processo é dividido em rotacional e translacional. O escorregamento translacional, na maior parte de suas ocorrências, está relacionado a intensas precipitações, que desencadeiam movimentos compridos e rasos, em superfície de ruptura planar. Logo, as características das encostas e as propriedades hidráulicas dos materiais envolvidos neste processo são considerados fatores condicionantes de sua gênese. Quando o material escorrega pela encosta sem que ocorram alterações significativas em sua estrutura, temos o escorregamento rotacional, à medida que este é o resultado de uma percolação profunda e lenta. FERNANDES \& AMARAL (2011) ressaltam que a existência de solos espessos e homogêneos favorece este tipo de movimento. Muitas vezes, este também está associado a intervenções artificiais, tais como a implantação de estradas e naturais, como, por exemplo, erosão fluvial no sopé de encostas.

A queda de blocos é um processo instantâneo no qual há a queda de blocos de rocha por conta da ação gravitacional sem que seja evidenciada a presença de uma superfície de deslizamento. O desprendimento destes blocos é favorecido pela presença de descontinuidades nas rochas e pela ação do intemperismo. FERNANDES \& AMARAL (2011), apontam que tais movimentos ocorrem nas encostas íngremes de paredões rochosos e contribuem para a formação de depósitos de tálus.

Por último, temos o rastejamento (creep), que é caracterizado por um movimento lento da rocha ou do solo, equivalente a alguns centímetros por ano. As causas deste movimento são: o pisoteio do gado, crescimento de raízes, escavação de buracos por animais, auxiliado pela presença da água na sua forma solida ou liquida SUERTEGARAY (2008). Por isso, pode ser percebido através da observação de troncos e postes inclinados em encostas, assim como outros elementos fixos.

Cabe ressaltar, que todos estes movimentos apresentados são decorrentes de condicionantes geológicos e geomorfológicos, tais como fraturas, falhas e morfologia das encostas, que atuaram no passado e, podem ainda ocorrer. Esta morfologia, pode condicionar a ocorrência de um movimento de massa seja de forma direta ou indireta. Diretamente, o movimento esta relacionado à relação existente entre a declividade da encosta e a frequência de movimentos. Entretanto, cabe enfatizar que o fator declividade não é determinando na ocorrência de movimentos de massa. É importante considerar também, as variações no tipo de cobertura vegetal e o fato de que em encostas mais íngremes, entende-se que os solos já podem ter sido removidos em eventos anteriores. Já a atuação indireta, diz respeito a função desempenhada pela forma da encosta na 
geração de zonas de convergência e divergência dos fluxos de água superficiais e subsuperficiais. Deste modo, segundo FERNANDES \& AMARAL (2011), as porções côncavas de relevo, os hollows, desempenham papel na concentração dos fluxos de água e sedimentos e, diante de tais condições de convergência, torna-se segmentos preferenciais da paisagem para a ocorrência de deslizamentos.

\section{A INFLUENCIA DA GEOMORFOLOGIA NOS GEOSISTEMAS E NA GEOECOLOGIA DA PAISAGEM}

Para abordarmos os geossistemas, é necessário, primeiramente, um breve entendimento da formação do conceito de paisagem. Diferentes e importantes escolas do pensamento geográfico ofereceram contribuições neste processo, tais como as escolas Russo-Soviética e Alemã, com uma abordagem da paisagem mais voltada para as questões biofísicas e, a Escola Francesa, com uma abordagem de cunho mais sociocultural. As primeiras ideias sobre a interação dos fenômenos naturais surgiram numa tentativa de integração frente à visão compartimentada da paisagem na Geografia. As contribuições do geógrafo francês Paul Vidal de La Blache e do geógrafo alemão Alexander Humboldt, ainda no século XIX, são então, primordiais. La Blache apresentou sob influência dos naturalistas, uma percepção da paisagem relacionada à sua gênese, inserida em uma abordagem estético-descritiva. Tendo como pilar também o naturalismo, mas concebendo a paisagem como descritiva e morfológica, Humboldt trouxe uma abordagem mais científica desta. Para ele, a planta tem um o papel de grande integradora da Geografia Física. Essa integração para Humboldt é percebida através do "olhar a paisagem", nas quais as plantas buscam na água os sais minerais e, à medida que fazem isso, se integram com o sol. Cabe, entretanto, um adendo no que diz respeito à visão holísta ${ }^{1}$ de Humboldt, na qual o mundo é a unidade na diversidade: apesar de toda visão holísta ser integrada, nem toda visão integrada é holísta.

SANSOLO (2007) ao abordar o surgimento do conceito geográfico de Paisagem, discorre sobre a origem dessa palavra através das representações linguísticas e também, acerca das representações da paisagem na pintura. A finalidade a qual se propõe a Geografia segundo ele, para La Blache, é a compreensão do encadeamento e das correlações dos fenômenos de uma região. Logo, Pays denotaria um lugar de escala maior que uma região e, sendo assim, a fisionomia a resultante da relação temporal entre os habitantes de determinada região e seus recursos naturais.

A divisão fisionômica da Paisagem foi proposta por Carl Troll, biogeógrafo alemão que conceituou a paisagem como uma síntese geográfica. Há assim, a diferenciação das paisagens em naturais e culturais ${ }^{2}$, que para ele era feita conforme o grau das transformações promovidas pelos homens, que passam assim, a ganhar importância nas discussões de paisagem. Além dessa conceituação fisionômica da paisagem, Troll também diferenciou na paisagem, sua funcionalidade. Esta, resultante do exame de diversos geofatores, dentre os quais Troll denominou de ecótopo as diversas dimensões de unidades de paisagens que compõe sua estrutura, incluindo as de origem antrópica.

VITTE (2007) aponta que essa visão dualista da Geografia sobre a paisagem, natural e cultural, se desenvolveu impregnada pela ideologia do mercado, como o grande portador da racionalidade econômica e sociopolítica, tal como ocorreu com o processo de evolução do conceito de natureza, que de uma função mítica passou a ser considerada um recurso econômico. SANSOLO (2007) acrescenta que o que se define por paisagem cultural é fruto de uma intensa ação da sociedade sobre a natureza, capaz de alterar os ritmos e processos ecológicos. 
As primeiras noções de interação entre os componentes da paisagem começaram a surgir durante o período do desenvolvimento biogeomorfológico, a partir da conceituação de fisionomia e funcionalidade, feitas por Carl Troll no inicio do século XX. A natureza passa a ser vista a partir de uma função mais integradora, assumindo uma conotação de lugar ou território. ROSS (2009) aponta que está na noção de "paisagem ecológica", introduzida por Troll no final da década de 1930 e na ampliação do termo e conceito de ecossistema, por Transley nas décadas de 1940/1950, o suporte teórico para o Geossistema.

A cultura, entendida como a junção de aspectos políticos, econômicos e sociais, é incorporada por SAUER (1998) na discussão de estrutura da paisagem. Embora ainda contextualizada em uma abordagem naturalista, a paisagem está então relacionada às questões especificas de cada lugar, de modo que os processos que ocorrem não podem ser lineares. Logo, para ele a paisagem é definida como sendo o conceito unitário da Geografia e, embora esta deva acompanhar as mudanças da paisagem, seu foco é a superfície terrestre. Sua identidade é baseada em relações que ela estabelece com outras paisagens, constituindo assim, um sistema geral. Cabe ainda, um adendo acerca do papel da diversidade, uma vez que diferentes processos ocorrem dentro da paisagem, não se limitando a sua forma e refletindo assim, a importância do viés cultural na discussão dessas paisagens.

No Brasil, Aziz Ab'Saber recuperou o termo fisiologia da paisagem, onde esta era compreendida como o resultado de uma relação entre os processos passados ${ }^{3} \mathrm{e}$ os atuais ${ }^{4}$. A geomorfologia moderna, a fim de entender os processos morfoclimáticos e pedogenéticos atuais, buscava uma compreensão da fisiologia da paisagem. É preciso considerar que nessa busca, as estruturas geológicas não devem estar relacionadas a um tempo estático. É necessário considerarmos a dinâmica do sistema, de modo que temos o clima como o responsável pela reprodução de condições não climáticas nesse sistema. A contribuição de Aziz representou uma importante reformulação metodológica e instrumental nas pesquisas geomorfológicas desenvolvidas no país.

Ainda na década de 1960, o conceito de paisagem sofreu modificações, perdendo o seu caráter até então descritivo. Métodos sistêmicos e quantitativos surgiram e teve inicio o processo de desenvolvimento da Ecologia da Paisagem, que abordaremos mais a frente. O enfoque sistêmico é apontado como necessário por BERTALANFFY (2006), diante do surgimento de problemas de totalidade ${ }^{5}$, interação dinâmica e organização. Com a intensificação da necessidade de uma melhor integração entre as correntes espacial e funcional, a partir da década de 1970, surge a concepção sistêmica. RODRIGUEZ (2007) aponta que essa concepção está atrelada a pressupostos como: processos, formas, organização, função, inter-relação, interdependência e estruturas, nos permitindo assim, abordar níveis de relações. Porém, antes de problematizarmos o conceito de Geossistema, é interessante fazermos uma diferenciação entre ele e o conceito de ecossistema.

A Teoria Geral dos Sistemas, de Bertallanfy, e a percepção da paisagem como uma categoria de análise integradora, constituíram a base metodológica na qual o conceito de Geossistema foi criado pelo geógrafo e geobotânico russo Viktor Sotchava em 1977. O Geossistema foi fundamentado na relação do homem com o meio no qual ele está inserido, tendo como base, classes hierarquizadas do meio natural. Embora os geossistemas sejam fenômenos naturais, todos os fatores econômicos e sociais, influenciando sua estrutura e peculiaridades espaciais, são tomados em consideração durante seu estudo e suas descrições verbais ou matemáticas (SOTCHAVA, 1977). Deste modo, é constituído por complexos policêntricos e há conexões com a totalidade e seus aspectos funcionais, em uma relação de dependência mútua. 
Além disso, foram estabelecidas por ele, três ordens dimensionais do geossistema a partir de uma diferenciação de escala: planetária, regional e tipológica. Na caracterização desse meio natural, convergem dois princípios, o da homogeneidade e o da diferenciação. Eles atuam concomitantemente, onde as estruturas de classe homogêneas são chamadas de geômeros e as de estrutura diferenciada são chamadas de geócoros. Percebe-se assim, uma mudança de postura por parte dos geógrafos. Deslocase de uma posição passiva e uma Geografia analítico-descritiva para uma Geografia preocupada com a aplicação dentro de um discurso de desenvolvimento que leve em conta a conservação e preservação da natureza (ROSS, 2009).

Já o conceito de ecossistema, desenvolvido por Tansley em 1935, tem uma conotação biológica, no qual as conexões ocorrem apenas entre os organismos, estruturados em complexos monicêtricos. Posteriormente, serão estabelecidas relações entre os geossistemas e a Geoecologia da Paisagem e entre os ecossistemas e a Ecologia da Paisagem. Fazendo um adendo sobre a visão ecológica, BERTALANFFY (2006) a classifica em superficial e profunda. Assim, a visão superficial para o autor é antropocêntrica, à medida que a natureza é vista como mercadoria, onde há a atuação do homem negativo reforçando a separação homem/natureza. Na visão profunda, todos os seres vivos têm o mesmo valor, sendo, portanto, ecocêntrica. Aponta ainda, que a Teoria Geral dos Sistemas surgiu diante da perda do enfoque mecanicista na ciência, que negava a totalidade. Baseado na concepção organística, básica na biologia, afirma que devemos estudar não somente partes e processos isoladamente, mas também resolver os problemas encontrados na organização e na ordem que os unifica, resultante da interação dinâmica das partes.

O geossistema então corresponde a dados ecológicos relativamente estáveis. BERTRAND (1971) aponta que o geossistema é o resultado da combinação de fatores geomorfológicos (natureza das rochas e dos mantos superficiais, valor de declive, dinâmica das vertentes...), climáticos (precipitações, temperatura...) e hidrológicos (lençóis freáticos epidérmicos e nascentes, $\mathrm{pH}$ das águas, tempos de ressecamento do solo...). Logo, esses fatores correspondem ao "potencial ecológico" do geossistema, que irá atingir seu estado de clímax quando houver um equilíbrio entre o potencial ecológico e a exploração biológica, uma vez que estes contêm dados instáveis que variam no tempoespaço.

O geógrafo brasileiro Antônio Christofoletti, aponta a importância da abordagem holística sistêmica para a compreensão das entidades ambientais físicas. Para ele, é importante abordagem dos sistemas complexos. Estes, definidos como sendo composto por grande quantidade de componentes interatuantes, capazes de intercambiar informações com o seu entorno condicionante e capazes também, de adaptar sua estrutura interna como sendo consequências ligadas a tais interações CHRISTOFOLETTI (1980). Logo, são classificados em sistemas fechados, os quais dadas às condições iniciais não sofrem perda, tampouco recebem energia ou matéria com o ambiente que os circundam e, sistemas abertos. Este último, por manter relações com os demais sistemas circundantes, pode ser subdividido em:

- Sistemas fechados: quando ocorre troca de energia, recebimento e perda, mas não de matéria.

- Sistemas abertos: quando há constante troca de energia e matéria, tanto recebendo como perdendo.

Imbuídos na complexidade da perspectiva sistêmica estão conceitos tais como: equilíbrio (estático, estável, dinâmico e metaestável dinâmico), sensibilidade, resistência, limite crítico, retroalimentação (feedback), tempo de reação e tempo de relaxação. 
Entretanto, entendemos que para a presente proposta de estudo e caso, não cabe aqui um aprofundamento nestes conceitos.

RODRIGUEZ \& SILVA (2013) definem o sistema como um todo complexo, único, organizado, formado pelo conjunto ou combinações de objetos ou partes. Entretanto, mesmo que a análise sistêmica permita supor uma síntese da realidade, há a necessidade de compreendermos as visões dialética e metafisica, para não cairmos no reducionismo. A visão dialética permite o entendimento de qualquer objeto (paisagem, espaço, território ou ambiente) como uma totalidade dialética desde uma posição integradora e sistematizadora (RODRIGUEZ \& SILVA 2013). Enquanto a visão metafísica reduz o sistema a dados, fragmentando assim a totalidade.

Percebemos assim, que a Teoria Geral dos Sistemas atendia a uma tendência de várias disciplinas uma vez que os problemas de totalidade apareceram em vários ramos da física moderna. Fazendo uma ressalva acerca da noção de totalidade, SANSOLO (2007), enfatiza a importância da escala para compreensão dos lugares, à medida que só se compreenderia o lugar, com suas especificidades, através da contextualização da sua condição em diversas escalas espaciais. Logo, a relação das partes com o todo e o fato de um sistema nunca estar por isso, isolado como critérios gerais do pensamento sistêmico, nos leva a uma Teoria da Complexidade na Geografia. O objeto da Geografia passa a ser compreendido como sendo o estudo da organização espacial, resultante da interação de dois subsistemas, o geossistema e o sistema sócio-econômico-cultural.

Partindo da concepção geossitêmica, a última etapa de conceituação da paisagem está relacionada à inter-relação dos aspectos estrutural-espacial e dinâmico funcional das paisagens. A Geoecologia da Paisagem surge da necessidade por parte da ecologia, de se incorporar fundamentos teóricos e os resultados das investigações da ecologia (ecossistêmicas), do planejamento e gestão ambiental e territorial a sua análise. Deste modo, o conceito de paisagem é incorporado, causando uma reconceitualizaçao da ecologia.

Os primeiros fundamentos da Geoecologia foram propostos pelo cientista russo Dokuchaev, no final do século XIX. Ao desenvolver a Teoria da Paisagem Geográfica, utilizou não apenas um método clássico de análise paisagística, mas uma abordagem verdadeiramente ecológico-paisagística ao incluir, em seus estudos da utilização da natureza, o homem e a sociedade (VICENS, 2012). Ao estudar o problema da luta com a seca e a fome que determinava as colheitas críticas nas terras da Rússia, ele deu papel exclusivo ao complexo das paisagens para a existência do homem, e para as atividades produtivas (RODRIGUEZ \& SILVA, 2013).

A proposta da criação de uma ciência da Ecologia da Paisagem, data da primeira metade do século XX, por Troll. Mas, a partir dos anos de 1970, com a consolidação da concepção ambiental, viu-se a necessidade de integrar as correntes espacial (geográfica) e funcional (ecológica) ao estudar a paisagem RODRIGUEZ (2007). Deste modo, o termo foi redefinido para Geoecologia. Por analisar funcionalmente a paisagem, não são estudadas apenas as propriedades dos geossistemas em seu estado natural, mas sim, as interações existentes com os sistemas sociais e culturais, em uma dimensão sócioecológica.

VICENS (2012) destaca que as mudanças introduzidas por Troll se apoiaram na concepção de Ecossistema de Tansley, muito poderosa na época. Isso porque, a Geoecologia une em si a abordagem paisagística, que estuda a diferenciação espacial na superfície terrestre e a distribuição dos fenômenos naturais, e, a abordagem ecológica, incumbida das inter-relações funcionais dos fenômenos e sistemas naturais.

É importante então, a conceituação da paisagem como uma formação antroponatural. Esta consiste num sistema territorial composto por elementos naturais e 
antropotecnogênicos condicionados socialmente, que modificam ou transformam as propriedades das paisagens naturais originais (RODRIGUEZ, 2007). Nessa perspectiva, pode-se considerar a paisagem como: um sistema que contêm e reproduz recursos; como um meio de vida e da atividade humana; como um laboratório natural e fonte de percepções estéticas.

À medida que concebemos o homem como o produtor do espaço e não como agente, está na Geoecologia da Paisagem a base para o planejamento ecológico do território. E, embora ofereça uma contribuição essencial no conhecimento da base natural do meio ambiente, entendido como meio global, alguns aspectos devem ser considerados. O grau como a sociedade transforma a natureza, conforme os diferentes tipos de utilização; como essa relação homem/meio é percebida na paisagem; considerar como uma sociedade concebe o natural e como esse quadro mental se traduz nas projeções de uso e gestão de seu território, são alguns desses aspectos. Logo, dentro de sua concepção científica, como base para o planejamento ecológico do território, será analisada como um sistema de métodos, procedimentos e técnicas de investigação, do qual o propósito consiste na obtenção de um conhecimento sobre o meio natural.

\section{O PNMMT: HISTÓRICA DE USO E CARACTERIZAÇÃO GEOMORFOLÓGICA}

A preocupação acerca do estabelecimento de um conjunto de áreas protegidas no Brasil, instituídas por diferentes esferas de poder, data do inicio do século XX. Seguindo essencialmente o modelo norte americano do Parque de Yellowstone, esta ocorreu inicialmente, por conta do interesse na criação de áreas ecoturísticas, com grandes belezas cênicas e voltadas para o lazer. Podemos dizer que somente a partir da década de 1930 houve uma real preocupação com a preservação ambiental, uma vez que passou a serem instituídas medidas legais, tal como o Código Florestal de 1934. Conforme visto, este foi voltado para a preservação, assim como, para a regularização do recurso madeireiro e valorização da floresta na estrutura socioeconômica, segundo as escalas nas quais foram instituídas. Tais escalas foram estabelecidas de acordo com as tipologias de áreas a serem especialmente protegidas pelo próprio Código Florestal.

No entanto, somente depois da elaboração, por parte do IBDF do Plano de Sistema de Unidades de Conservação no Brasil, em 1979, tornou-se possível estabelecer bases legais para a posterior institucionalização do SNUC, em 2000. Logo, foram estabelecidos parâmetros para a criação e manejo de áreas protegidas no Brasil, nos quais foram criadas diversas categorias, de acordo com o grau de proteção. Deste modo, o Parque Natural Municipal Montanhas de Teresópolis, foi criado a partir do pressuposto pelo SNUC, no qual é classificado como uma unidade de proteção integral, uma vez que, está inserido na categoria de Parque Nacional, mas teve sua implementação conduzida pela esfera municipal. É importante destacarmos, neste contexto, que evolução no que diz respeito às politicas ambientais no Brasil não representou, todavia, a superação das questões relacionadas à separação homem-meio.

A proposta de criação do PNMMT, embora seja uma reivindicação antiga dos moradores de Teresópolis ${ }^{6}$, partiu do encontro entre Jorge Mario Sedlcek, até então candidato a prefeito do município pelo Partido dos Trabalhadores, e a ONG (Organização não-governamental) TereViva. Eleito, quando assumiu a prefeitura em 2009, recebeu a indicação por parte da TereViva, da pessoa que viria assumir o cargo de secretário do meio ambiente. Esta nomeação, conforme dito em conversa informal com o então diretor do PNMMT em 2011, foi feita tendo em vista a concretização da criação do Parque, à medida que a pessoa indicada já havia participado de processo semelhante em outra UC. 
Deste modo, houve por parte da secretaria de meio ambiente, grande preocupação para que o PNMMT integrasse o Mosaico Mata Atlântica Central Fluminense, a Reserva da Biosfera da Mata Atlântica e o Corredor de Biodiversidade Serra do Mar. A consequência prática disto seria, então, a potencialização da gestão integrada de diversas unidades de conservação locais, tal como, a APA de Petrópolis. Sobre isto, cabe enfatizar, que a gestão ambiental em mosaicos ganhou força a partir da instituição do SNUC. Com o Estado inibindo o comportamento predatório, passou a haver um estímulo a parcerias, no que diz respeito às formas de manejo dos recursos naturais. Logo, a preservação de remanescentes florestais do bioma Mata Atlântica existente na região, se consolidou ainda mais.

Conforme determinado no artigo 22 do SNUC, as Unidades de Conservação devem ser criadas por ato do poder público. São necessários durante este processo, estudos técnicos e consulta pública que, baseada nos princípios da democracia participativa, deve ser realizada após a população local tomar conhecimento de informações adequadas acerca da proposta de criação da unidade. Deste modo, é imprescindível a participação desta população nas discussões que antecedem a criação da UC, principalmente quando esta se encontra inserida na categoria de proteção integral, à medida que sua existência é incompatível com a prática de atividades econômicas predatórias. É o caso do PNMMT. Embora tenham sido realizadas reuniões com a população local com o intuito de conscientizá-la sobre a importância da conservação ambiental, alguns impasses sugiram justamente por conta de atividades econômicas praticadas nestas áreas. Além da criação de gado e da agricultura orgânica, havia também a extração irregular de granito, na área que foi incorporada ao PNMMT.

Diante destes impasses, evidencia-se que muitas vezes, para os habitantes locais, as unidades de conservação são vistas como imposições governamentais que restringem seus direitos tradicionais. Conforme visto anteriormente, existe hoje a necessidade da participação da sociedade enquanto sujeito fundamental das ações relacionadas à problemática ambiental. Isto ocorre, porque a partir do momento no qual se buscam medidas a fim de evitar a degradação ambiental, existe a conscientização da própria sociedade de que ela é o agente causador de tal degradação e, consequentemente, esta é um problema social. Todavia, não é considerado o fato de que muitos processos naturais ocorrem independentes da ação humana. Ao mesmo tempo, à medida que o homem transforma o ambiente, estes processos ditos naturais, podem ocorrer com maior intensidade. Nessa perspectiva, a compreensão do conceito de meio ambiente torna-se essencial, no sentido de que este deve estar atrelado à interação do homem com os fenômenos do mundo, tornando possível por meio desta troca, o planejamento e a gestão ambiental. Mas esta compreensão não foi considerada durante a delimitação da área do PNMMT.

O que ocorreu durante este processo, foi a separação das áreas ocupadas pelo homem, em sua maioria encostas com moradias, em relação aos remanescentes de Mata Atlântica da região. Não foram consideradas quais áreas era importante se preservar, mas sim, quais áreas era possível se preservar diante da ocupação humana já existente, logo, houve a separação das áreas ocupadas pelo homem, mesmo esta estando em sua zona de amortecimento $^{7}$. Tal processo justifica o contorno da área do PNMMT, que é bastante recortado. Tais medidas foram tomadas na época, para que não houvesse a necessidade de indenizar as centenas de famílias que viviam na região. Posteriormente, veremos a mudança do discurso do poder publico diante de tais moradias, o que mostra que os critérios utilizados no processo de delimitação do PNMMT poderiam ter sido outros. Além disso, atualmente, ainda existem propriedades privadas dentro da área do parque, mas como estas pertencem a "poderosos" da cidade, nenhuma medida foi tomada até então. 
Neste cenário, o PNMMT foi criado por meio de Decreto Municipal n ${ }^{\circ} 3.693$ de julho de 2009, após um processo de estudos técnicos e consultas públicas que se estendeu ao longo de seis meses. Sua inauguração "coincidiu" com a comemoração do aniversário da cidade de Teresópolis, 06 de julho. Mesmo diante de grandes esforços para a consolidação do parque, a Secretaria Municipal do Meio Ambiente (SMMA) encontrou sua primeira dificuldade diante dos poucos recursos disponibilizados. Desta forma, as parcerias foram, segundo a secretaria, de suma importância para a concretização deste projeto. Ocorreram desde as consultas públicas, e, inicialmente, desempenharam papel fundamental em sua gestão, inclusive na elaboração de estudos para o seu plano de manejo, que ainda está em curso. Assim, a equipe técnica da SMMA realizou desde a criação do parque, contatos com os representantes de instituições governamentais que atuam na região, com organizações comunitárias e lideranças locais, no intuito de concretizar a criação do Conselho Consultivo do Parque. As principais parcerias foram realizadas com a Secretaria de Estado do Ambiente, o Instituto Estadual do Ambiente e com o Atlantic Forest Conservation Fund (AFCoF) - Fundo de Conservação da Mata Atlântica - Funbio, co-financiado pela República Federal da Alemanha através do KfW Entwicklungsbank.

Entendemos como necessária para a problematização do processo de criação do PNMMT, a compreensão da evolução do modo como se pensa a natureza, uma vez que para a população local, muitas vezes esta é vista apenas como recurso por conta de suas atividades econômicas. Com a mudança acerca do entendimento da natureza, torna-se possível a busca de medidas que cujo principal intuito seja a sua preservação. Entretanto, mesmo após o "entendimento" da relação homem/meio por parte dos agentes envolvidos, a delimitação da área do parque foi pautada no principio preservacionista de separação destes. Isso ocorreu justamente para que este fosse implementado sem que houvesse a necessidade de remover e/ou indenizar a população que mora/morava no seu entorno, como se ambos não integrassem um só sistema ecológico.

Como sabemos os sistemas não podem ser entendidos por meio de partes, mas sim, dentro de um contexto maior. É justamente esse enfoque sistêmico que nos permite uma análise geoecológica da paisagem. Nesse tipo de análise, à medida que se buscam as interações dos sistemas sociais e culturais dentro de uma dimensão sócio-ecológica frente às propriedades do sistema, é possível ter a visão integrada de sua unidade com o meio natural. Deste modo, a partir da interação deste meio com os sistemas sociais, são formados os sistemas ambientais. Conforme visto em RODRIGUEZ (2007), a geoecologia da paisagem, como base para o planejamento ecológico do território, será então, um sistema de métodos, procedimentos e técnicas de investigação com a finalidade de obter o máximo de conhecimento acerca do meio natural. Logo, podemos perceber esta integração sistêmica, na brusca interrupção do processo de implementação do PNMMT, por conta da tragédia que assolou a região serrana em janeiro de 2011.

No que diz respeito a sua caracterização física, PNMMT está localizado no município de Teresópolis, na região serrana do Estado do Rio de Janeiro (Figura1). A região está inserida no domínio morfoclimático que Aziz Ab’Saber classificou como Mares de Morros, sob o clima tropical úmido. O PNMMT está inserido em uma região que possui importantes remanescentes florestais da Mata Atlântica, abrigando assim, várias espécies da fauna e flora nativas. Logo, junto com as outras unidades de conservação existentes no município, o PARNASO e o Parque Estadual dos Três Picos (PETP), passa a integrar, através de uma pequena ligação, o Mosaico Mata Atlântica Central Fluminense. 
Figura 1 - Mapa de localização do PNMMT

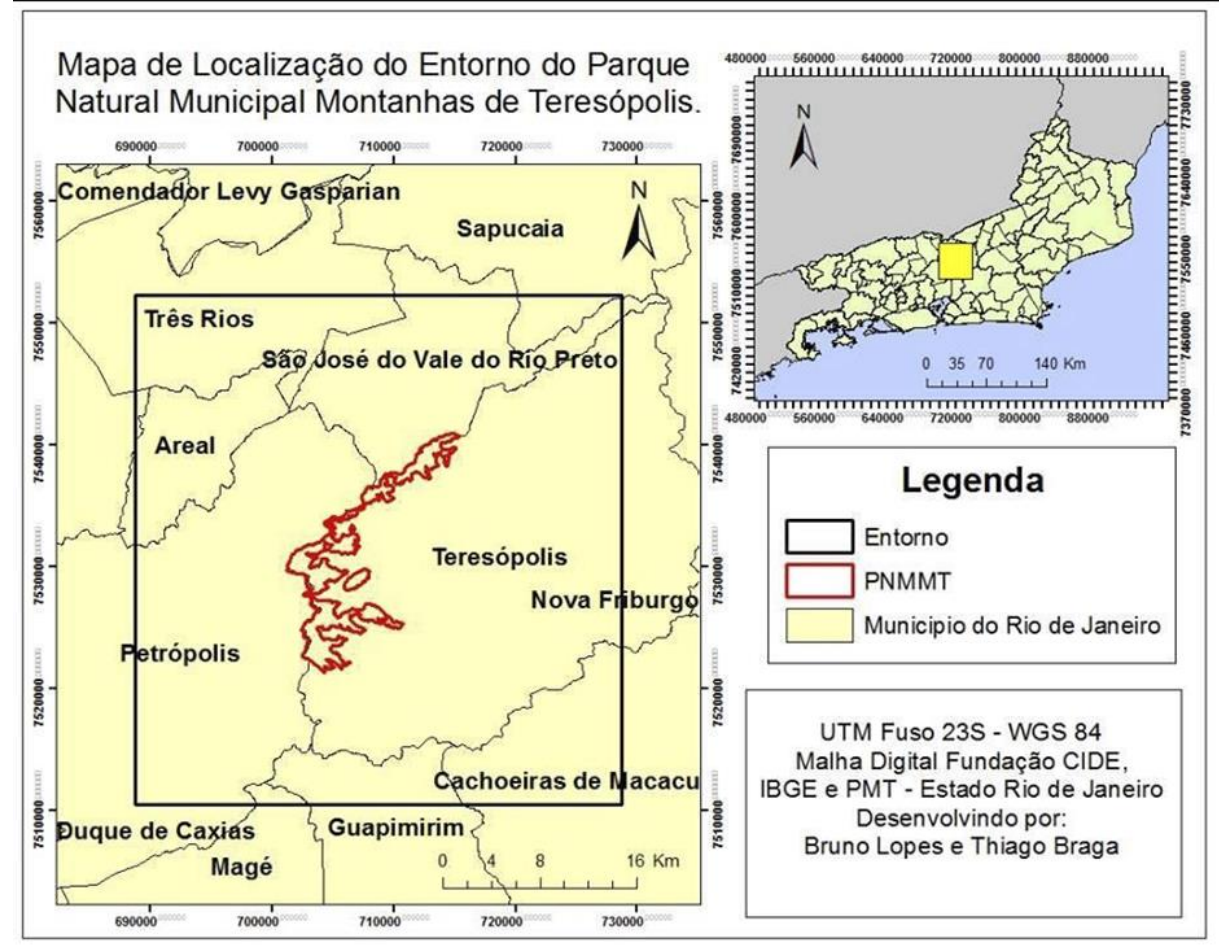

O estudo do desenvolvimento de determinada bacia hidrográfica é de suma importância no que diz respeito à compreensão da evolução da paisagem. Deste modo, para os estudos integrados da paisagem, a análise morfométrica surge como um método que busca mostrar não apenas as características de formas e processos predominantes nas bacias hidrográficas, mas também as interações de maneira quantitativa. Os produtos destas análises tornam possíveis a caracterização geomorfológica da área e, consequentemente, o entendimento dos processos geomorfológicos e hidrodinâmicos predominantes. Além disso, têm sido cada vez mais importantes no planejamento e gestão ambiental por auxiliarem, por exemplo, na busca por soluções de problemas ambientais e na definição de áreas a serem recuperadas.

Nesse sentido, podemos definir a análise morfométrica de bacias hidrográficas como um conjunto de procedimentos metodológicos orientados através da investigação e compreensão cientifica de componentes constituintes de uma bacia hidrográfica. De acordo com o Instituto Brasileiro de Geografia e Estatística (IBGE, 2009), os estudos relacionados a cursos fluviais através de métodos sistêmicos e racionais como parâmetros quantitativos, podem levar a elucidação de variadas questões acerca da morfogênese e morfordinâmica da paisagem, uma vez que a rede de drenagem é de suma importância no que diz respeito à compartimentação do relevo.

Logo, os parâmetros morfométricos que foram definidos, na presente análise foram: desnivelamento da bacia hidrográfica, densidade de drenagem, eficiência de drenagem, declividade e gradiente da bacia. É importante ressaltar, que os fatores morfométricos não se restringem a estes apenas e que, para a determinação de tais coeficientes, são imprescindíveis, por exemplo, fatores topográficos, geológicos, geomorfológicos e de uso e ocupação do solo. 


\section{PARÂMETROS MORFOMÉTRICOS NAS ENCOSTAS MONTANHOSAS DO PMNMT: CONTRADIÇÕES ENTRE O GEOSSISTEMA E A DELIMITAÇÃO DA UNIDADE DE CONSERVAÇÃO}

Para o cálculo das variáveis geomorfológicas, foram utilizados os dados disponibilizados gratuitamente no banco de dados geomorfométricos do Brasil - Topodata que oferece o Modelo Digital de Elevação (MDE) e suas derivações locais básicas em cobertura nacional. Estes são elaborados a partir dos dados SRTM disponibilizados pelo USGS na rede mundial de computadores. O projeto Topodata foi lançado em 2008, mas após alguns aprimoramentos em seu processamento de dados, uma nova versão culminou em uma metodologia passível de aplicação sempre que existirem SRTM. Esta é a metodologia a qual utilizamos.

Para o cálculo da amplitude de relevo do PNMMT (Figura 2), com o auxílio do Topodata e de dados topográficos do IBGE (1:50.000), foram traçadas as bacias hidrográficas cujas nascentes se encontram na área do parque, considerando os limites das bacias de terceira ordem. Logo, foram calculados os níveis de base para cada uma destas bacias, definidos a partir da confluência de rios de $3^{\circ}$ ordem, ou da cota altimétrica da foz dos rios de menor ordem. Deste modo, com os limites hidrográficos e com os valores de altitude absoluta, foi calculado o nível de base para cada sub-bacia e, a amplitude do relevo em cada ponto. Os procedimentos utilizados para a identificação dos domínios geomorfológicos do PNMMT foi a mesma aplicada pelo IPT (Instituto de Pesquisas Tecnológicas) em 1981 ao elaborar o Mapa Geomorfológico do Estado de São Paulo (Tabela 1). Os principais critérios utilizados foram os de declividade dominante das vertentes e amplitude de relevo. 
Figura 2 - Mapa de Amplitude do Relevo no PNMMT. Projeção Cilíndrica Equiretângular

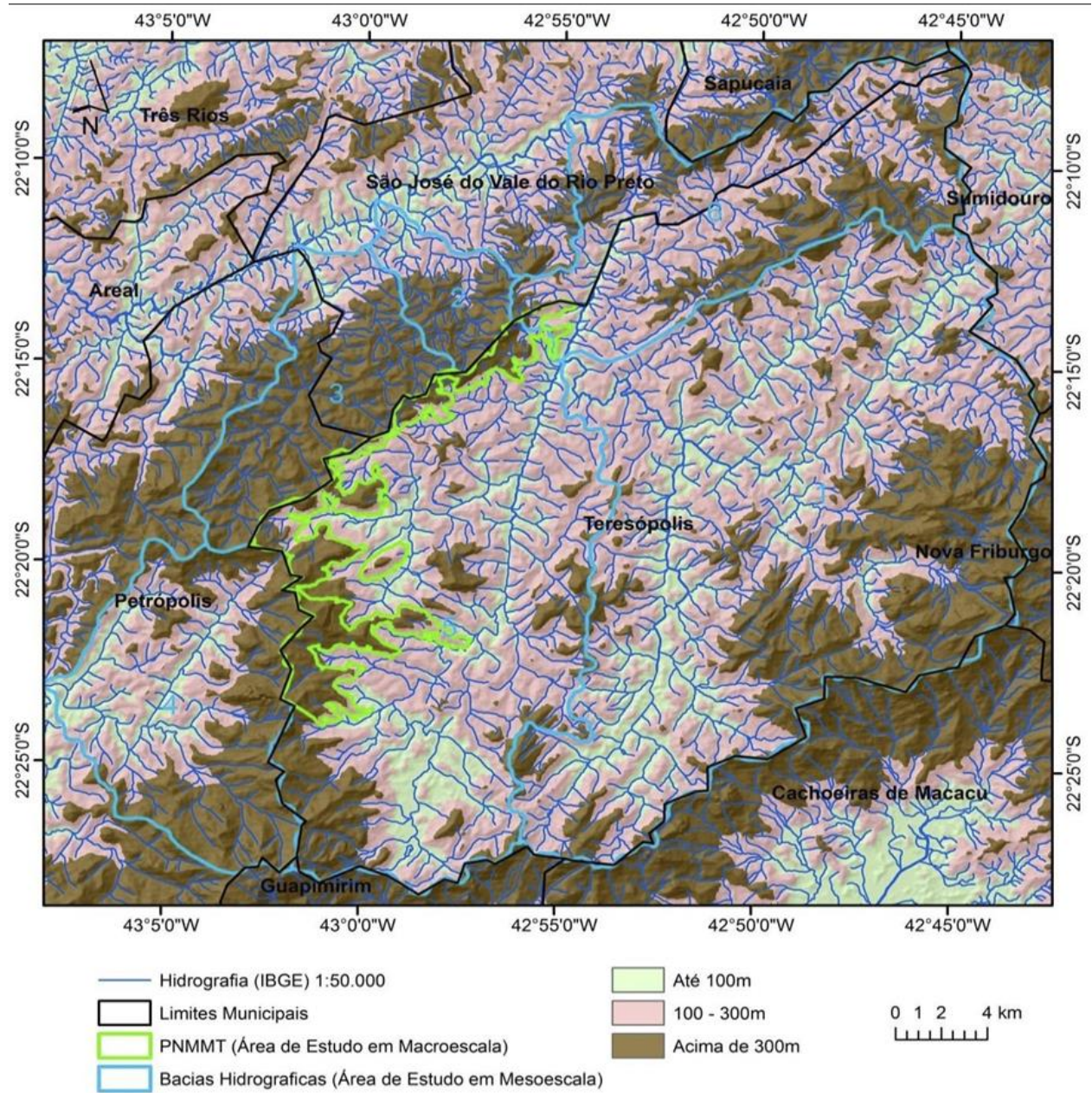

Fonte: LABGEO/UERJ-FFP.

Tabela 1 - Classes de Sistemas de Relevo para o Estado de São Paulo

\begin{tabular}{|l|l|l|}
\hline Sistemas de Relevo & Declividade & Amplitude do Relevo \\
\hline Relevo Colinoso & $0 \%$ a $15 \%$ & $<100 \mathrm{~m}$ \\
\hline $\begin{array}{l}\text { Morros com Vertentes } \\
\text { cunriandac }\end{array}$ & $0 \%$ a $15 \%$ & De $100 \mathrm{~m}$ a $300 \mathrm{~m}$ \\
\hline Morrotes & $>15 \%$ & $<100 \mathrm{~m}$ \\
\hline Morros & $>15 \%$ & De $100 \mathrm{~m}$ a $300 \mathrm{~m}$ \\
\hline Montanhoso e/ou Escarpado & $>15 \%$ & $>300 \mathrm{~m}$ \\
\hline
\end{tabular}

Fonte: IPT (1981).

É importante destacar, que conforme aponta SEABRA (2012), a amplitude do relevo refere-se à diferença entre a altitude de um ponto e a altitude do nível de base local. A amplitude relativa de um relevo é dada pelas alturas ou cotas relativas, que não devem ser confundidas com a altitude absoluta, que é tomada em relação ao nível do mar ou superfície de referência. Cabe destacar, que para subsidiar a compartimentação geomorfológica da área do PNMMT e seu entorno, foi realizado o levantamento de dados 
morfométricos das bacias inseridas na área, tais como: densidade de drenagem; índice de eficiência de drenagem; bacias de drenagem de $2^{\circ}$ ordem; declividade; gradiente dos canais.

Na presente análise morfométrica da área do PNMMT e seu entorno, foram estabelecidos quatro parâmetros que servirão de subsídio para a produção do mapa de domínios geomorfológicos da mesma. Desta forma, a caracterização concentrou-se na elevação da área, em seu desnivelamento, no gradiente das bacias e na densidade de drenagem. As bacias são utilizadas para a compartimentação topográfica do relevo, o que permite que as sub-bacias que fazem parte do sistema hidrográfico sejam classificadas de acordo com sua dinâmica geomorfológica. Logo, tais sub-bacias podem representar diferentes significados no que diz respeito ao escoamento hidrológico, conforme os parâmetros controladores da eficiência do processo de drenagem, como gradiente e densidade de drenagem.

Entendemos como amplitude altimétrica, na diferença entre a elevação máxima e mínima. Esta variação na elevação exerce influencia em fatores como a variação na precipitação anual e a temperatura média, que causa variações sobre as perdas de água, por evapotranspiração. Através da análise do mapa de elevação, foi possível constatar que a maior parte da área estudada, com exceção da porção na qual estão inseridos o Vale do rio Paraíba do Sul e a zona de transição entre as escarpas e a Baixada Litorânea, encontrase em altitude acima dos 500 metros. Neste contexto, o PNMMT está localizado em altitude que varia entre 1000 e 1500 metros, com pequenas áreas que apresentam uma variação na elevação, entre 1500 e 2000 metros. As áreas nas quais foram registradas altitude maior do que 2000 metros, encontram-se localizadas nas bordas da escarpa da Serra do Mar.

O desnivelamento é o resultado da diferença entre os pontos mais altos e mais baixos da bacia, tendo como parâmetro um nível relativo que não o do mar. GUERRA (2008) alerta que o desnivelamento é dado pelas alturas ou cotas e não deve ser confundido com a altitude absoluta, que é tomada em relação ao nível do mar. A partir das alturas encontradas, foram estabelecidas três classes de desnivelamento para as subbacias analisadas: domínio de colinas, morrotes e morros baixos (entre 109 e 397m); domínio de morros elevados (entre 397 e 748m) e domínio montanhoso (entre 748 e $1542 \mathrm{~m})$.

Das 441 sub-bacias inseridas na área de estudo, 54,4\% delas apresentaram um baixo desnivelamento, inseridas então no domínio de colinas, morrotes e morros baixos. A maior parte destas sub-bacias está localizada nas porções nas quais fazem parte o Vale do rio Paraíba do Sul e a zona de transição entre as escarpas e a Baixada Litorânea. Entretanto, também foi possível observar a presença de um baixo desnivelamento em subbacias ligadas a outras, classificadas como morros elevados, demonstrando assim, uma transição entre estes domínios de baixo e médio desnível.

Dentre as sub-bacias classificadas dentro do domínio de morros elevados, temos $31,7 \%$ do total. Estas evidenciam uma brusca transição entre domínios quando ligadas á sub-bacias que apresentam um alto desnivelamento, como as escarpas da Serra dos Órgãos. E, quando ligadas a sub-bacias com um baixo desnivelamento, corroboram uma transição mais suave entre os domínios. Por último, dentre as sub-bacias analisadas, apenas $13,9 \%$ apresentaram um alto desnivelamento e por isso fazem parte do domínio montanhoso, no qual há o predomínio de escarpas.

É importante ressaltar, que esta distribuição é decorrente da localização da área analisada, na qual a altitude mínima é de 109 metros. Tais resultados acerca do desnivelamento da área de estudo, estão diretamente relacionados ao gradiente dos canais fluviais das respectivas bacias. Uma vez que fluxo de água será o reflexo também, de tais 
características geomorfológicas. Logo, à medida que a declividade dos cursos de água é indicada, pode-se estabelecer o potencial de energia do canal em questão, através de sua capacidade de escoamento superficial.

Por meio da análise das informações obtidas em relação ao gradiente, constatouse que há o predomínio de bacias com médio gradiente, no qual fazem parte $61,5 \%$ das bacias, seguido das de baixo $(20,5 \%)$ e alto (18\%). Estabelecemos então uma relação entre os dados do gradiente de drenagem dos canais analisados e os dados relativos ao desnivelamento dos mesmos. Nas bacias cujo desnível é alto, o gradiente também tende a ser alto, com exceção de algumas bacias da Serra dos Órgãos, que apresentam um médio gradiente. As bacias que têm um baixo ou muito baixo desnivelamento, o gradiente de drenagem é médio ou baixo. Entretanto, existem algumas bacias que apesar de apresentarem um desnível médio ou baixo, têm um alto gradiente de drenagem. Possivelmente, isto ocorre por estarem localizadas em bordas de escarpas ou, em alguns casos, porque apesar do desnivelamento ser médio ou baixo, estão em áreas cuja altitude varia entre 1000 e 1500 metros.

Dentro da área do PNMMT o padrão que aponta o predomínio do médio gradiente de drenagem permanece. Em sua porção sul, o parque é caracterizado por um alto desnivelamento, o restante de sua área tem um desnível médio e ainda, em uma parte menor cujo desnível é baixo. Estabelecendo uma relação entre estes dados e seu gradiente de drenagem, é possível observar, conforme dito anteriormente, que há na maior parte do PNMMT o médio gradiente, seguido por áreas de baixo e alto. Deste modo, podemos constatar as bacias analisadas apresentam de forma geral, uma declividade relativamente alta, capaz de ocasionar um fluxo de água que tende a ser rápido.

Logo, segundo SEABRA (2012), a obtenção do índice do gradiente das sub-bacias serve como auxilio no que diz respeito à compreensão do potencial de susceptibilidade erosiva das bacias. De acordo com o autor, áreas que apresentam altos valores de declividade criam sérias dificuldades para estabelecimento de diversas atividades humanas, reduzindo com isso as pressões antrópicas existentes sobre os ecossistemas ali presentes. Deste modo, tornam-se mais altos os valores de favorabilidade à recuperação ambiental nestas áreas. Entretanto, a recuperação de áreas degradadas é desfavorecida por conta dos processos erosivos decorrentes da alta declividade. Estes, por serem mais significativos, ocasionam dificuldades no que diz respeito ao acumulo de água e nutrientes. Em contrapartida, nas áreas baixa declividade, há uma maior facilidade de acesso e de estabelecimento de atividades antrópicas, aumentado assim a pressão sobre os fragmentos existentes e reduzindo as chances de recuperação.

A densidade de drenagem de uma bacia correlaciona o comprimento total dos canais de escoamento com a área da bacia. O calculo da densidade de drenagem apresenta uma relação inversa com o comprimento dos rios, na qual, à medida que há o aumento do valor numérico da densidade, há a diminuição quase proporcional do tamanho dos componentes fluviais das bacias. Logo, podemos relacionar a densidade de drenagem com o índice de eficiência de drenagem. Entretanto, não se pode tomar como regra, a relação de que quanto maior a área da bacia, menor será sua densidade de drenagem. De acordo com CHRISTOFOLETTI (1980), esta é uma das variáveis mais importantes na analise morfométrica, pois é o resultado da relação existente entre o clima, a vegetação e sua litologia. Segundo ele, em um mesmo ambiente climático, o comportamento hidrológico das rochas irá repercutir na densidade de drenagem.

Dentre as 84 bacias que apresentam uma alta densidade de drenagem, a maior parte tem um alto desnivelamento e, apresentam também um gradiente de drenagem classificado entre alto e médio. Entretanto, existem bacias que tem uma alta densidade de drenagem apesar de apresentarem um baixo desnivelamento e um baixo gradiente. 
Podemos concluir deste modo, que embora as bacias que apresentam uma alta densidade de drenagem estejam em grande parte localizadas no domínio montanhoso da Serra do Mar, não á apenas nesta área que estão localizadas.

Dentre as bacias que apresentam uma média densidade de drenagem, em sua maioria, predominam os médios desnivelamentos, embora o gradiente destas esteja bem distribuído entre as classificações de médio e baixo. Algumas poucas bacias possuem um alto gradiente e/ou alto desnivelamento, mesmo apresentando uma média densidade de drenagem. Por ultimo, nas bacias com uma baixa densidade de drenagem, o desnivelamento é classificado como de baixo para médio. Existem algumas exceções que apresentam um alto desnivelamento. Estas, porém, estão localizadas em ambientes de escarpas. E, no que diz respeito ao gradiente destas bacias, a maioria apresenta um médio gradiente de drenagem, seguidas pelas de alto e baixo gradiente.

A partir destas analises, foi possível identificar quais bacias possuem um maior ou menor potencial de fluxo de água e, assim, tomar conhecimento da intensidade de processos erosivos relacionados à esculturação dos canais fluviais. Neste sentido, observamos que as bacias que apresentam uma baixa densidade de drenagem, tendem a estar localizadas em regiões nas quais há o predomínio de rochas impermeáveis e/ou com um baixo índice pluviométrico. Por outro lado, estão localizadas em regiões com o relevo montanhoso, as bacias cujos canais têm um alto índice de densidade de drenagem. Isto ocorre devido à ausência de uma grande resistência à erosão, por conta das características litológicas e de solos rasos ali existentes.

Partimos então, para a identificação dos domínios geomorfológicos do PNMMT e seu entorno, na qual foram utilizados os critérios estabelecidos a partir da metodologia utilizada pelo IPT (1981), na elaboração do Mapa Geomorfológico do Estado de São Paulo. Esta metodologia, que apresentou resultados satisfatórios para a compreensão do relevo do Estado do Rio de Janeiro, está representada junto ao Mapa de Domínios Geomorfológicos do PNMMT e seu entorno (Figura 3). Este é produto dos dados de amplitude de relevo e declividade, extraídos do nível de base das bacias analisadas e, tendo como base os sistemas de relevo estabelecidos pelo IPT (1981). 
Figura 3 - Mapa dos Domínios Geomorfológicos do PNMMT e entorno. Projeção Cilíndrica Equiretângular

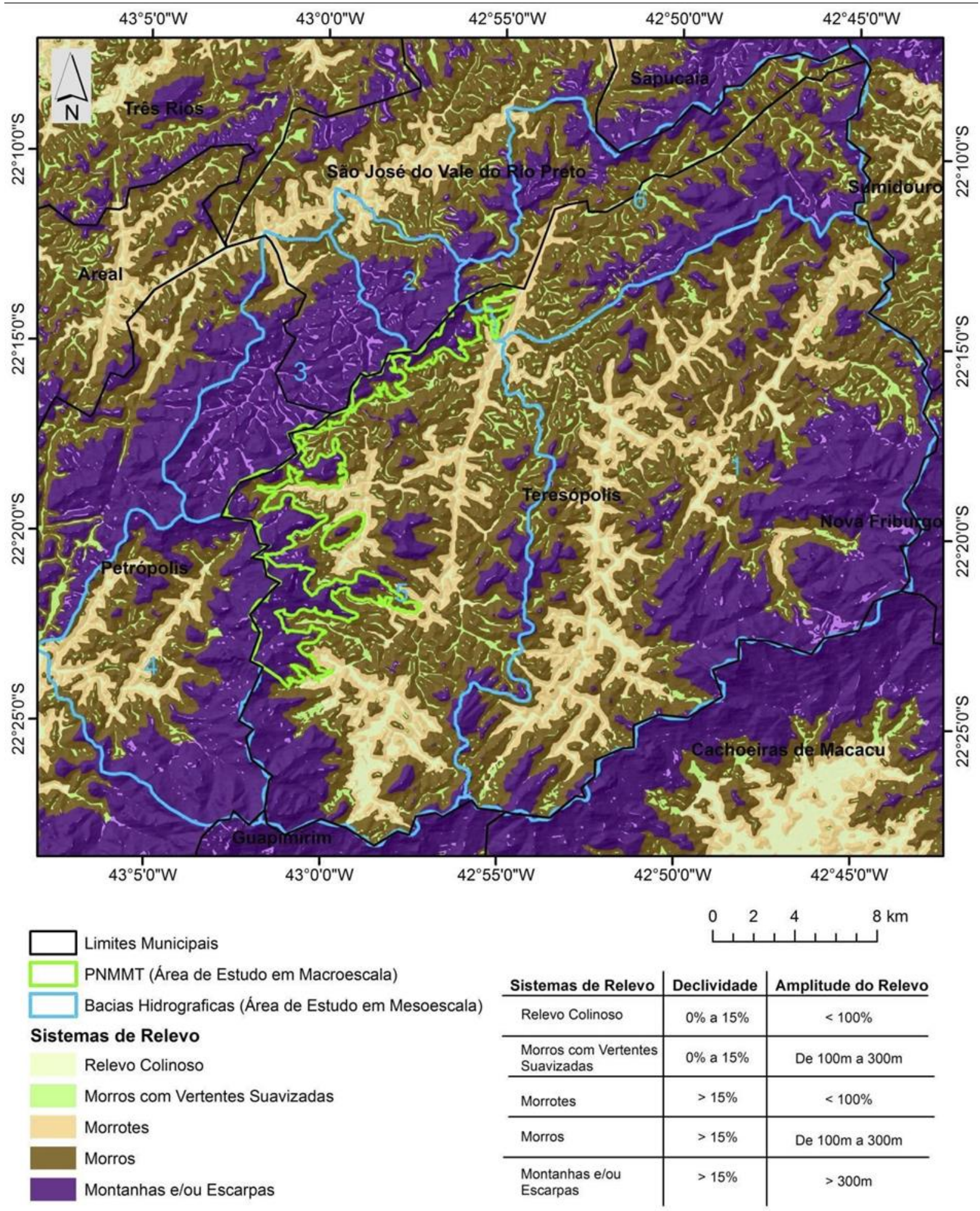

Fonte: LABGEO/UERJ-FFP.

Através da análise do Mapa de Domínios Geomorfológicos, podemos observar que este se mostrou compatível com a realidade da presente área de estudo. Deste modo, o resultado final indica que há o predomínio do Domínio de Montanhas e/ou Escarpas, seguido do Domínio de Morros. Este padrão se mantém na área do PNMMT, 
com a presença de Morros em um pequeno pedaço e em suas bordas na porção leste. $\mathrm{O}$ Domínio de Morrotes está localizado entre os morros e as colinas, às margens dos canais fluviais, como nas bacias do Rio Paraíba do Sul e do Rio Paquequer. Inseridos em meio aos morrotes, está o Domínio de Morros com Vertentes Suavizadas. Por último, o Domínio Colinoso, encontra-se nas zonas de convergência dos canais das bacias dos rios Paraíba do Sul, Piabanha, Paquequer e na zona de transição entre as escarpas e a Baixada Litorânea. Logo, à medida que a classificação geomorfológica proposta pelo IPT (1981) mostrou-se compatível com a área de estudo, foi traçado o perfil topográfico da mesma, a fim de corroborar os resultados encontrados (Figura 4).

Figura 4 - Perfil topográfico da área do PNMMT e entorno

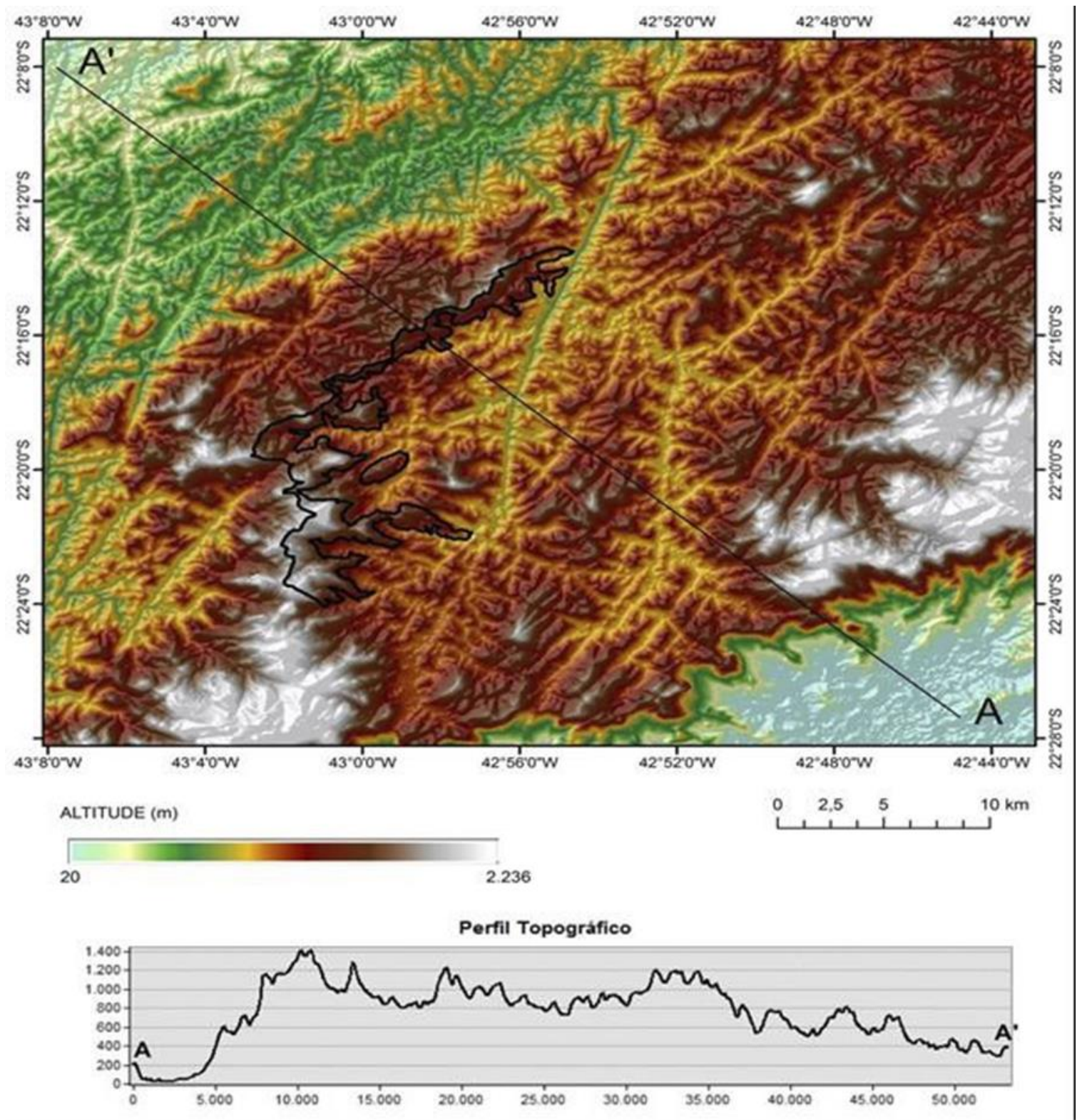

Concebemos assim, a compreensão da dinâmica hidroerosiva na área do PNMMT e seu entorno como de suma importância para a realização do presente diagnóstico geoecológico, uma vez que, sua ênfase está na geomorfologia. Desta forma, faz-se necessário o entendimento do índice de eficiência de drenagem, a fim de apreender a relação entre seu potencial erosivo, sua densidade de drenagem e sua morfologia. 
O Índice de Eficiência de Drenagem é uma resultante analítica-integrativa que, de acordo com FERNANDES et. al. (2006), revela a importância de determinados parâmetros geomorfológicos que exercem influência no escoamento d'agua de uma bacia de drenagem. Este índice é determinado através da relação existente entre o gradiente de drenagem da bacia (Gd) e a densidade de drenagem (Dd) desta. Logo, é definido como o reflexo destes dois parâmetros, resultando da variação das leituras da drenagem do relevo no que diz respeito às águas superficiais de uma bacia. Com base no cálculo do índice de eficiência de drenagem da área do PNMMT e seu entorno, constatou-se que das 441 bacias analisadas, 13,4\% apresentam um alto índice de eficiência de drenagem. Estas estão em sua maioria localizadas nas regiões de escarpas serranas, as quais são caracterizadas também por uma alta ou média densidade de drenagem, assim como, por um alto ou médio gradiente. Estas combinações resultam em áreas com o relevo bastante dissecado, por conta da interação de sua morfologia, que está inserida no domínio montanhoso, sua elevada declividade e os altos índices pluviométricos da região.

Dentre as bacias que são caracterizadas por um médio índice de eficiência de drenagem, estão 36,2\% do total analisado. Estas, embora também estejam localizadas em áreas de escarpas, encontram-se ainda em outras áreas. Estão bem distribuídas entre bacias que têm alta e média densidade de drenagem. Conquanto, algumas poucas estão inseridas em bacias com uma densidade de drenagem baixa. Porém, no que diz respeito ao gradiente destas bacias, estes podem ser classificados como médios ou baixos. Logo, podemos concluir que o índice de eficiência de drenagem destas bacias corresponde ao comportamento esperado, com base nas análises morfométricas realizadas anteriormente.

Finalmente, podemos concluir que as análises morfométricas realizadas, geraram produtos que se mostraram compatíveis com a realidade. $\mathrm{O}$ mapeamento dos domínios geomorfológicos da área do PNMMT e entorno, foi realizado por meio da metodologia do IPT (1981), sem que fosse necessária qualquer adaptação e, assim como as análises morfométricas, mostrou-se compatível com a realidade. Logo, é possível questionar quais critérios foram utilizados para a delimitação desta área.

Outro elemento que reitera essa conclusão está justamente no evento catastrófico ocorrido na madrugada do dia 12 de janeiro de 2011, no qual uma forte chuva que atingiu sete cidades da região serrana do estado do Rio de Janeiro, afetando, sobretudo as cidades de Teresópolis, Nova Friburgo e Petrópolis. Grande parte da área do PNMMT foi afetada por movimentos de massa, assim como, muitas casas de seu entorno, nas quais moradores perderam tudo e/ou vieram a falecer (Figura 5). De acordo com DOURADO et al. (2013), este foi considerado um dos maiores eventos de movimento de massa generalizados no Brasil no qual, oficialmente, 947 pessoas morreram, 300 desapareceram e mais de 50.000 ficaram desabrigadas, afetando quase 1.000 .000 pessoas. No município de Teresópolis, 392 pessoas morreram, mas, este número tende a ser bem maior do que os divulgados oficialmente. Apenas no bairro de Campo Grande, que foi totalmente devastado, viviam mais de 6.000 pessoas segundo dados da companhia de energia da região, divulgados na mídia. 
Figura 5 - Mapa com a distribuição das cicatrizes do evento de 2011 na Região Serrana do Rio de Janeiro

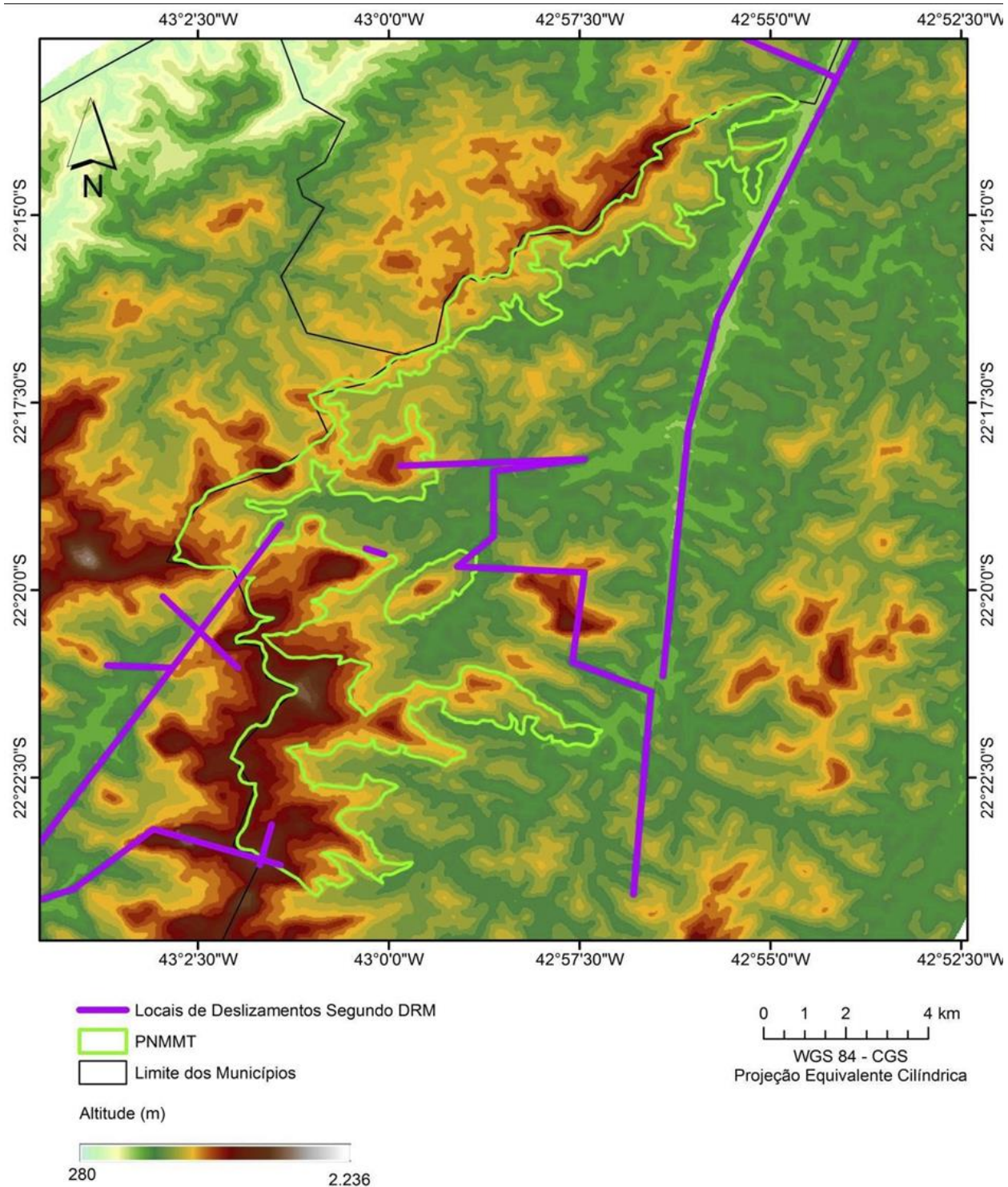

Fonte: DRM, 2011 (Modificado). ${ }^{8}$

O modo como a área do parque e toda a população vizinha foi afetada pelos eventos catastróficos, evidenciou que ao se ignorar o ambiente que está inserido no sistema integrado, houve a abertura de uma brecha para a ocorrência um abalo natural de grande magnitude, mas não esperado pela população. Logo, reiteramos a afirmação de RODRIGUES (2001), de que os geossistemas, embora sejam considerados "fenômenos naturais", devem ser estudados à luz dos fatores econômicos e sociais que influenciam sua estrutura, uma vez que estes são um conjunto de elementos que se relacionam entre si formando uma integridade. Observamos então, que a delimitação e a consequente criação do PNMMT deveria estar atrelada à politicas públicas de habitação, dada a localização das moradias no entorno do parque, em áreas de encostas. Porém, apesar do histórico de movimentos de massa na região, tais áreas foram consideradas de "risco", apenas após os eventos extremos de janeiro de 2011. Se tais medidas tivessem sido 
tomadas no processo de criação do PNMMT, sem que a praticidade fosse priorizada, muitas vidas poderiam ter sido poupadas.

\section{CONSIDERAÇÕES FINAIS}

Como podemos observar ao longo desse artigo existe uma evidente contradição entre os aspectos ambientais do geossistema, o processo de ocupação das encostas e a delimitação da unidade de conservação. As características geomorfológicas da área demonstram uma situação de elevada suscetibilidade a eventos erosivos, especialmente os movimentos de massa, que possuem grande potencial de degradação das encostas e de repercussão nos fundos de vale adjacentes. Portanto torna-se necessário o questionamento da delimitação da área do PNMMT, no que diz respeito a sua abrangência, conforme as finalidades propostas. Ora, uma vez que uma das principais intenções embutidas na criação do parque é sua inserção no Mosaico da Mata Atlântica Central Fluminense, existe apenas uma pequena ligação através do domínio montanhoso, em sua porção sul com o PARNASO. Suas ligações com a APA de Petrópolis e com o Parque Natural Municipal do Araponga, em São José do Vale do Rio Preto, não constam no mapeamento disponível no site do Mosaico, o qual, na verdade, não consta o PNMMT. Entretanto, conforme observamos no mapa de Domínios Geomorfológicos do PNMMT e seu entorno, há a possibilidade de ligá-lo ao Parnaso, justamente por conta do predomínio do relevo montanhoso entre estas duas UC. Desta forma, além da preservação dos remanescentes de Mata Atlântica da região, ficaria assegurada a não construção de moradias em áreas instáveis geologicamente.

\section{NOTAS}

1 - A abordagem holística é definida por CHRISTOFOLETTI (1999) como a concepção de que o todo possui propriedades que não podem ser explicadas em termos de seus constituintes individuais.

2 - Entendemos como paisagens culturais, a paisagem como resultante da ação da cultura ao longo do tempo, modelando-se assim, por um grupo cultural, a partir de uma paisagem natural.

3 - Entendemos como processos passados, os responsáveis pela compartimentação regional da superfície.

4 - Entendemos que os processos atuais respondem pela dinâmica atual da paisagem.

5 - De acordo com CHRISTOFOLETTI (1999), a totalidade aplica-se às entidades constituídas por um conjunto de partes, cuja interação resulta numa composição diferente e específica, independente da somatória dos elementos componentes.

6 - Existe um interesse histórico de conservação da área da pedra da Tartaruga, onde hoje está inserido o PNMMT. Este resultou no artigo 205 da Lei Orgânica Municipal que, promulgada em abril de 1990, tomba a Pedra da Tartaruga, por esta ser indispensável à história, beleza e ao meio ambiente.

7 - Entendemos como Zona de Amortecimento os territórios localizados no entorno das unidades de conservação, onde é permitido o desenvolvimento de atividades pelo homem desde que não prejudiquem sua conservação.

\section{REFERÊNCIAS BIBLIOGRÁFICAS}

BERTALANFFY, L. V. Teoria geral dos sistemas. 6. ed. Petrópolis: Vozes, 2006.

BERTRAND, G. Paisagem e geografia física global: esboço metodológico. Caderno de Ciências da Terra, n. 13, p. 1-27, 1971. 
CHRISTOFOLETTI, A. Geomorfologia. 13. Reimpressão. São Paulo: Blucher, 1980.

COELHO NETTO, A.L. Hidrologia em interface com a geomorfologia. In: GUERRA \&CUNHA (Org.) Geomorfologia: uma atualização de bases e conceitos. 12. Ed. Rio de Janeiro: Ed. Bertrand Brasil, 2013.

DOURADO, F.: ARRAES, T. C.; SILVA, M. F. O Megadesastre da Região Serrana do Rio de Janeiro - as Causas do Evento, os Mecanismos dos Movimentos de Massa e a Distribuição Espacial dos Investimentos de Reconstrução no Pós-Desastre. Anuário do Instituto de Geociências - UFRJ, 2013.

FERNANDES, M. C. et al. Domínios Geo-Hidroecológicos do Maciço da Tijuca, RJ: Subsídios ao Entendimento dos Processos Hidrológicos e Erosivos. Anuário do Instituto de Geociências, v. 29 - 2, p. 122-148, 2006.

FERNADES, N. F.; AMARAL, C. P. do. Movimentos de Massa: uma abordagem geológico-geomorfológica. In: GUERRA, A. J. T. \& CUNHA, S. B. da. Geomorfologia e Meio Ambiente. Rio de Janeiro: Bertrand Brasil, 2011. 394 p

GUERRA, A. T., Dicionário Geológico e Geomorfológico. 6. ed. Rio de Janeiro: Bertrand Brasil, 2008.

- Processos Erosivos nas Encostas. In: GUERRA \& CUNHA (Orgs.) Geomorfologia: uma atualização de bases e conceitos. 12. Ed. Rio de Janeiro: Ed. Bertrand Brasil, 2013.

IBGE - Instituto Brasileiro de Geografia e Estatística. Manual Técnico de Geomorfologia. MANUAIS Técnicos em Geociências, n 5 .2.ed.. Rio de Janeiro, 2009.

IPT - Instituto de Pesquisas Tecnológicas. Mapa geomorfológico do estado de São Paulo. São Paulo, 1981.

MENDONÇA, F. Geografia Socioambiental. In: MENDONÇA, F. \& KOZEL, S. (Orgs.). Elementos de Epistemologia da Geografia Contemporânea. Curitiba, Ed. UFPR, 2004.

MOREIRA, R. Para onde vai o pensamento geográfico? Por uma epistemologia crítica. 1. ed., 2. Reimpressão. São Paulo: Contexto, 2009.

ROCHA LEÃO, O.M. (2005) "Propagação e controle de voçorocamentos em cabeceiras de drenagem: potencialidades e limitações da revegetação, Bananal/SP". Tese (Doutorado), PPGG/IGEO, Universidade Federal do Rio de Janeiro, Rio de Janeiro.

RODRIGUES, C. A Teoria Geossistêmica e sua Contribuição aos Estudos Geográficos e Ambientais. Revista do Departamento de Geografia, 14, p 69-77, 2001.

RODRIGUEZ, J. M. M., SILVA, E. V. Planejamento e Gestão Ambiental: Subsídios da Geoecologia das Paisagens e da Teoria Geossistêmica. Fortaleza: Edições UFC, 2013. 
RODRIGUEZ, J. M. M., SILVA, E. V. e CAVALCANTI, A. P. B. Geoecologia das Paisagens: uma visão geossistêmica da análise ambiental. 2. ed. Fortaleza: Edições UFC, 2007. 222p.

ROSS, J. Ecogeografia do Brasil: subsídios para planejamento ambiental. São Paulo: Oficina de Textos, 2009.

SANSOLO, D. G. Significados da paisagem como categoria de análise geográfica. In: Anais do VII Encontro da ANPEG. Niterói, 2007.

SAUER, C. O. A Morfologia da Paisagem. In: CORREA, R. L. e ROSENDHAL, Z. Paisagem, tempo e cultura. Rio de Janeiro: Ed. UERJ, 1998. p. 12-74.

SEABRA, V. S. (2012) "Análise da paisagem em apoio aos estudos de favorabilidade à recuperação florestal na bacia hidrográfica do rio São João". 244 páginas. Tese (Doutorado). PPGG/IGEO, Universidade Federal do Rio de Janeiro, Rio de Janeiro.

SOTCHAVA, V. B. Estudo de Geossistemas. Métodos em Questão, n 16. São Paulo: IG. USP, 1977.

SUERTEGARAY, D. M. A. (Org.). Terra: feições ilustradas. 2. ed. Porto Alegre: Editora da UFRGS, 2008.

VICENS, R. S. Geografia da Paisagem e Ordenamento Territorial. In: BARBOSA, J. L. \& LIMONAD, E. (Orgs.). Ordenamento Territorial e Ambiental. Niterói: Editora da UFF, 2012.

VITTE, A. C. O desenvolvimento do conceito de paisagem e a sua inserção na Geografia Física. Mercator. Revista de Geografia da UFC, ano 6, n. 11, 2007. 